\title{
Corporate Brand Image and Customer Satisfaction on Loyalty: An Empirical Study of Starbucks Coffee in Taiwan
}

\author{
*Yu-Te Tu, Chin-Mei Wang, Hsiao-Chien Chang \\ Chungyu Institute of Technology, Taiwan \\ *suntu@ms18.hinet.net
}

\begin{abstract}
Corporate image has been assessed as an important antecedent of customer satisfaction and loyalty. Corporate brand is vital because positive corporate brands help companies achieving higher performance, such as sales. Marketing exists to deliver more value to satisfy customers as well as build a long-term and mutually profitability relationship with customers. If a firm's products or services do not satisfy or meet the customer's needs and wants, all the strategies are insufficient. With loyal customers, companies can have higher market share and reduce the operating cost. An improvement of 5 percent in customer retention leads to an increase of 25 percent to 75 percent in profit. It costs more than five times as much to obtain a new customer than to keep an existing one. This initial study was from relevant literature, then set up research structure and hypotheses. Survey was employed, and respondents were from the customers of Starbucks Coffee in Taipei area. There were 199 usable questionnaires to analyze descriptive statistics, reliability, validity, and SEM model. The research found that corporate brand image significantly affects customer satisfaction and customer loyalty, and customer satisfaction has strong impact on customer loyalty for the sample. Therefore, firms have to specifically focus on these factors in order to build a long-term and mutually profitability relationship with a customer and create loyalty as competitive advantages in the market.
\end{abstract}

Keywords: Corporate brand image, customer satisfaction, loyalty, SEM

\section{Introduction}

Starbucks Coffee Company, established in 1971, is the world's largest coffee chain with its headquarters located in Seattle, USA. Starbucks Taiwan was officially established on January 1, 1998 by a joint venture of Starbucks Coffee International and Uni-President, and it has opened 223 Starbucks Coffee shops in 2009. Presently, Starbucks Coffee faces more competitive than usual because of $85^{\circ} \mathrm{C}$ Café, convenient stores and fast food chains. Martenson (2007) indicated that customers to a favorable store image might affect perception of store brand. De Chertanony and Harris (2000) reported that corporate brand is vital because positive corporate brands help companies achieving higher performance, such as sales. Marketing exists to deliver more value to satisfy customers as well as build a long-term and mutually profitability relationship with customers (Kotler, 2005). If a firm's products or services do not satisfy or meet the customer's needs and wants, all the strategies are insufficient. The ultimate goal for companies to build customer loyalty is generally the central marketing activities (Eakuru \& Mat, 2008; Oliver, 1997). With loyal customers, companies can have higher market share and reduce the operating cost (Aaker, 1997).

Reichheld and Sasser (1990) indicated that an improvement of 5 percent in customer retention leads to an increase of 25 percent to 75 percent in profit. Wills (2009) reported that it costs more than five times as much to obtain a new customer than to keep an existing one. Moreover, with loyal customers, for example, companies can increase their revenue. First, loyal customers are less price sensitive, and the premiums of loyal customers increase 8 percent annually in the personal insurance industry (Reichheld \& Teal, 1996). Second, loyal customers are willing to purchase frequently, try the firms' other products or services, and bring new customers to the firms (Reichheld \& Sasser, 1990). At Northwestern Mutual, the contribution of 55 percent sales is from existing customers (Reichheld \& Teal, 1996). Reichheld and Teal (1996) further indicate that customer loyalty provides a foundation for a firm to examine their marketing strategy, relationship quality improvement activities, and value creation program. The study seeks to develop a conceptual framework of brand image, customer satisfaction on customer loyalty. The purpose of study is (1) to evaluate the relationship of corporate brand image and customer satisfaction, (2) to 
assess the relationship of customer satisfaction and customer loyalty, and (3) to analyze the relationship of corporate brand image and customer loyalty.

\section{Literature Review}

Corporate brand image: Davies, Chun, Da Silva and Roper (2003) indicated that anything could be a brand, such as a company, corporate or name. Keller (1993) defined brand image is a perception about a brand held in consumer memory. Corporate brands are intangible assets for companies that are difficult to imitate, and it is different from products brands as emphasizing the important of brand values (De Chertanony, 1999). Ind (1997) reported that when consumers purchase products from a company, they not only buy products but also receive a set of values form the company. Corporate brands are a sum of values representing the corporate (Ind, 1997), and a positive corporate brand image is not only help companies to increase competition but also encourage consumers to re-purchases (Porter \& Claycomb, 1997). Consumers more favorable the image has higher perceived in quality, value, satisfaction and loyalty (Johnson, Andreessen, Lervik, \& Cha, 2001).

Customer satisfaction: Satisfaction can be separated into two approaches either as a transaction-specific satisfaction (Olsen \& Johnson, 2003) or as a cumulative satisfaction/post-consumption satisfaction (Oliver, 1997). After 1990s, many researchers view satisfaction as customers' cumulative, after purchase, and overall judgment about purchasing behavior (Johnson, Anderson \& Fornell, 1995; Engel \& Blackwell, 1982; Hunt, 1977; Oliver, 1997). According to Oliver (1997), satisfaction is defined from the mixture of both affection (emotion) and cognition approach as "the consumer's fulfillment response. It is a judgment that a product or service feature, or the product or service itself, provided (or is providing) a pleasurable level of consumption-related fulfillment, including levels of under- or over-fulfillment" (Oliver, 1997). Customer satisfaction is viewed as influencing repurchase intentions and behavior, which, in turn, leads to an organization's future revenue and profits. However, Bowen and Shoemaker (2003) stated that satisfied customers might not return to the firm and spread positive word-of-mouth communications to others. One of the reasons is that the firm does not deliver what customers need or want (Roig, Garcia, Tena \& Monzonis, 2006). Woodruff (1997) further identified that customer satisfaction measurement without fulfillment of customer perceived value could not really meet the customer's expectations. Therefore, other variables should exist to further explain the relationship between satisfaction and customer loyalty.

Customer loyalty: Customer loyalty can be classified as brand loyalty, service loyalty, and store loyalty (Dick \& Basu, 1994). Customer loyalty is a strategy that creates mutual rewards to benefit firms and customers (Reichheld \& Detrick, 2003). One benefit is that firms can increase the revenue. With loyal customers, companies can maximize their profit because loyal customers are willing to (1) purchase more frequently; (2) spend money on trying new products or services; (3) recommend products and services to others; and (4) give companies sincere suggestions (Reichheld \& Sasser, 1990). Thus, loyalty links the success and profitability of a firm (Eakuru \& Mat, 2008). Customer loyalty is commonly distinguished in three approaches including behavioral loyalty approach (Grahn, 1969); attitudinal loyalty approach (Bennett \& Rundle-Thiele, 2002; Jacoby, 1971; Jacoby \& Chestnut, 1978), and integration of attitudinal and behavioral loyalty approach (Dick \& Basu, 1994; Jacoby, 1971; Jacoby \& Chestnut, 1978; Oliver, 1997). The attitudinal loyalty helps to examine the factors of loyalty, to avoid switching behavior (Caceres \& Paparoidamis, 2007), and to predict how long customers will remain loyal (Jacoby \& Chestnut, 1978). Therefore, viewing loyalty as an attitude-behavior relationship allows integrated investigation of antecedents and consequences of customer loyalty (Dick \& Basu, 1994).

Corporate brand image, customer satisfaction and loyalty: Corporate image has been assessed as an important antecedent of customer satisfaction and loyalty $(\mathrm{Wu}, 2011)$. In the previous study, Davies et al. in 2003, has shown a positive relationship between corporate brand image and satisfaction, and this result is consistent with the theory proposed by Davies et al. Martineau (1958) stated that if consumers favor image of the store, they will probably develop a certain degree of loyalty, and Selnes (1993) also confirmed the influence of corporate brand image on brand loyalty. However, Davies and Chun (2002) found that corporate brand image had an indirect influence on brand loyalty via customer satisfaction when personality traits are used to portray corporate brand image in an off-line setting. Customer satisfaction is an important driver to customer loyalty and the success of businesses (Oliver, 1997). 
Studies have found positive evidence on the direct relationship between customer satisfaction and loyalty of repeat purchase, less price sensitive, cross-buying behavior, and profit (Bloemer \& Odekerken-Schroder, 2002; Ibrahim \& Najjar, 2008; Oliver, 1997). However, several studies (Dimitriades, 2006; Jones, 1996; Woodruff, 1997) show that satisfied customers do defect. For example, when customers say they are satisfied, they still purchase elsewhere (Jones, 1996).

Therefore, based on the above discussion of literature review, the theoretical propositions inform the development of following hypothesized model and research hypotheses.

\section{Figure 1: Hypothesis Model}

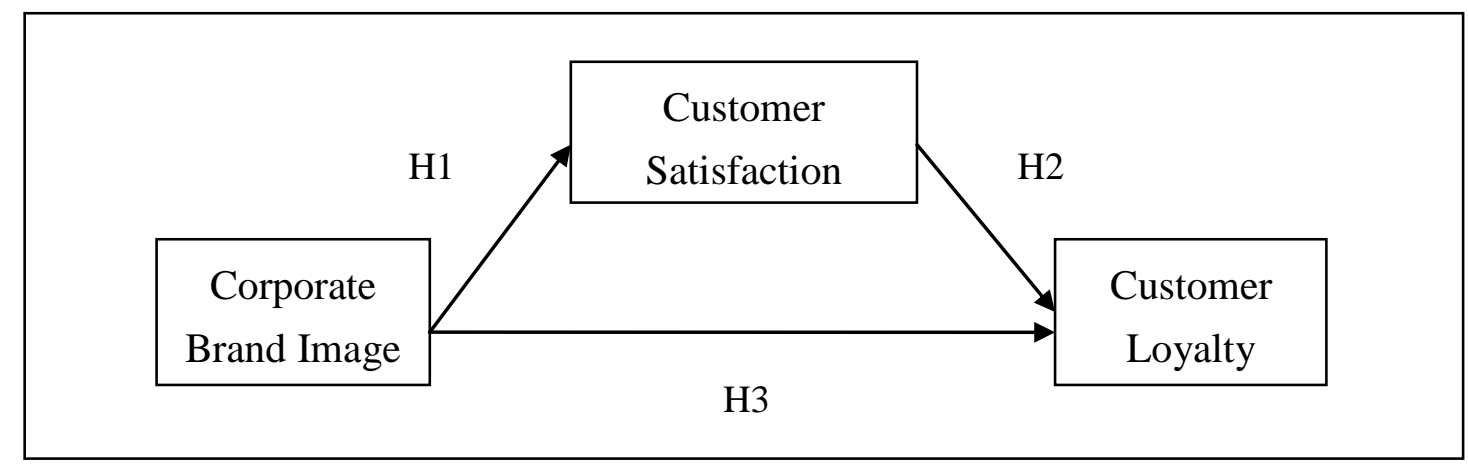

\section{Research hypotheses:}

H1: The corporate brand image is a direct path and is a factor that significantly affects the customer satisfaction.

$\mathrm{H} 2$ : The customer satisfaction is a direct path and is a factor that significantly affects the customer loyalty.

H3: The corporate brand image is a direct path and is a factor that significantly affects the customer loyalty.

\section{Methodology}

A quantitative, non-experimental, exploratory (comparative) and explanatory (correlational) study was conducted to assess the relationships among corporate brand image and customer satisfaction on customer loyalty.

Instrumentation: A four-part questionnaire for the study was developed by the researchers in order to measure the research variables. In the questionnaire, seven of the items were designed to examine corporate brand image according to the theory of Ind in 1997 and De Chertanony in 2000; five of the items were designed to examine customer satisfaction according to the theory of Oliver in 1997; and five of the items were developed to test customer loyalty according to the theory of Reichheld and Sasser in 1990. All variables are by means of a five-point Likert scale, and ranged from strongly agreeing (5) to strongly disagree (1). These socio-demographic questions and the coding schemes used included: Gender: 1 = male; 2 = female. Age: 1 = under 25; $2=25-35 ; 3=36-45$; and $4=$ over 46. Education: $1=$ high school diploma or equivalent; 2 = associate degree; 3 = bachelor degree; and 4 = graduate degree.

Population: The survey was distributed to customers in a public area outside the main entrance of Starbucks Coffee shops during the weekday and weekend in Taipei area. A random sampling plan was used to select participants. When customers agreed to participate, participants were given a survey questionnaire on a clipboard, and retrieved the questionnaire after finished.

Methods of data analysis: Hair, Black, Babin, and Anderson (2010) indicated that structural equation modeling (SEM) has become a popular multivariate approach because it provides a means of assessing theories that is conceptually appealing. AMOS software (version 18.0), which includes an SEM package with maximum likelihood estimation, was used to test both the measurement and the structural models that related to the research hypotheses listed. The present research also made use of a number of criteria to determine the inclusion of items and the goodness of fit of the model. Hair et al. (2010) suggested a six-stage procedure for employing SEM, which the research also followed here. First, EFA was used to 
pretest the questionnaire in order to reduce the items to a manageable and meaningful set of factors, and the reliability of the internal consistency was measured using Cronbach's coefficient alpha. Results of the Kaiser-Meyer-Olkin (KMO) test and of Bartlett's test were obtained before performing the factor analyses. The KMO test indicated whether a sufficient number of items had been predicted by each construct, and Bartlett's test indicated whether the items were sufficiently highly correlated to provide a reasonable basis for factor analysis.

Cronbach's coefficient alpha was used to analyze the variables related to the scales of each item, according to the average correlation of each item with every other item. Leech, Barrett and Morgan (2005) recommended that KMO values should be greater than 0.7, and Bartlett's test should be significant. A factor loading of 0.50 or above was considered to be of practical significance (Hair et al. 2010). The lower limit for Cronbach's coefficient alpha values was 0.7 (Leech, Barrett \& Morgan 2005). The validity of the construct was measured using the convergent and discriminant validity. The convergent validity was used to determine whether scale items converged on a single construct during measurement (Steenkamp \& Van Trijp 1991). This was determined from the evaluation of the factor loadings (which must be at least 0.5), composite reliability (at least 0.6 ) and average extracted variance (at least 0.5) in the study (Hair et al. 2010; Fornell \& Larcker 1981). The discriminant validity is the extent to which a construct is truly distinct and unique, and this measure captures phenomena that other measures do not (Hair et al. 2010).

Hair et al. (2010) indicated that the goodness-of-fit of the overall model is indicated by how well it reproduces the observed covariance matrix among the indicator items. It can be classified into the following four categories: Chi-square measures including chi-square, degree of freedom (df) and probability. Measures of absolute fit, including the goodness-of-fit index (GFI), root mean square error of approximation (RMSEA), root mean square residual (RMR), standardized root mean square residual (SRMR) and normed chi-square. Incremental fit measures including the normed fit index (NFI) and the comparative fit index (CFI). Parsimony fit measures including the adjusted goodness-of-fit index (AGFI) and the parsimony normed fit index (PNFI). Chi-square $\left(\chi^{2}\right)$ is a basic measurement of the differences between the observed and estimated covariance matrices (Hair et al. 2010). A smaller value of $\chi^{2}$ is more desirable in that it supports the proposed theoretical model, but values of $\chi^{2}$ also increase as the sample size increases. The p-value should be large and not statistically significant $(p>0.05)$ between the two matrices (Jöreskog \& Sörbom 1992). GFI was an early attempt to produce a fit statistic. The range of possible GFI values is between 0 and 1 , and if the value is 0.90 or higher the fit is considered to be good (Hair et al. 2010); however, MacCallum and Hong (1997) suggested that the GFI value could decrease to 0.80 in usage.

RMSEA tries to correct for both the sample size and complexity of the model by including each in its computation. Steiger (1990) suggested that RMSEA values below 0.10 indicate a good fit. Hair et al. (2010) indicated that RMR is problematic because it is related to the scale of the covariances. An alternative statistic is SRMR, which is useful for comparing the fit across models. Jöreskog and Sörbom (1992) indicated that an acceptable SRMR value would be 0.05 or less. The normed chi-square is given by $\chi 2 / \mathrm{df}$, and its value should be 3 or less to indicate a better fit between the observed and modeled values (Hair et al. 2010). NFI is the ratio of the difference in the value of $\chi^{2}$ between the fitted and null models, divided by the value of $\chi^{2}$ for the null model (NFI = 1 is a perfect model; Hair et al. 2010). Bentler (1992) suggested that the value of NFI should be 0.90 or above. The CFI is an improved version of NFI. It ranges between 0 and 1, with values above 0.90 being associated with a good fit (Hair et al. 2010; Gerbing \& Anderson 1992). AGFI takes into account different degrees of complexity in the model, and its value is usually lower than that of the GFI in complex models (Hair et al. 2010). MacCallum and Hong (1997) recommended that the value of AGFI should be 0.80 or higher to indicate a good fit. The PNFI adjusts the NFI by multiplying it by the parsimony ratio; high values represent a better fit (Hair et al. 2010). Wu (2009) indicated that the value of the PNFI should be 0.50 or above to indicate a good fit.

\section{Results}

There were 206 questionnaires collected, but 7 questionnaires were incomplete or invalid. All questionnaires were coded for statistical analysis using the SPSS 14.0. From the 199 respondents, in total, $80(40.2 \%)$ respondents were male and $119(59.8 \%)$ were female. $36(18.1 \%)$ of the respondents were 
under 25 years old, 51 (25.6\%) were between 25 and 35, 71 (35.7\%) were between 36 and 45 and 41 $(20.6 \%)$ were older than 46. In the study, $26(13.1 \%)$ respondents had a high school diploma or equivalent, $41(20.6 \%)$ held an associate degree, $93(46.7 \%)$ held a bachelor's degree and $39(19.3 \%)$ had a graduate degree. The three dimensions and 17 items were evaluated by EFA. For the first-time EFA, all items of the factor loadings less than .60 were deleted. For the second-time EFA, the KMO value of the variables used in the study was .938 , indicating that the data from the results were sufficiently robust to allow EFA. The values of Bartlett's test were $\chi^{2}=2266.998, \mathrm{df}=105$ and $\mathrm{p}=.000$, which implies that all the items in this study were sufficient for research in social science and for factor analysis. The extraction and rotation sums of the squared loading of the total variance explained were $74.318 \%$. Five items remained for each dimension, which could therefore now be applied. The four dimensions of Cronbach's coefficient alpha were between .907 and .910, which surpassed the criteria and indicated an internal reliability of the consistency of the instruments used in the present study that was appropriate for research in social science. Because of EFA, three factors and 15 items were therefore derived to identify the construct.

The univariate normality of the skewness and kurtosis values and the multivariate normality were used to assess the normality. The most commonly used critical values of univariate normality are \pm 3 and \pm 10 (Kline, 1998). In the study, all the values of skewness were between .171 and -.905, and the values of peakedness lay between 1.654 and -1.045 . The observed variables all had univariate normal distributions. The value of Mardia statistic is for multinormality measurement, and it is constructed a test based on skewness and kurtosis. Bollen (1989) indicated that if the value of Mardia is smaller than $p$ $(p+2), p$ indicating the amount of observed variables, all dimensions are multinormality. In the study, the value of Mardia is 34.542, smaller than $15(15+2)$, indicating multivariate normality distribution. In the structural models, all the factor-loading estimates were higher than .76, the composite reliability (CR) values ranged from .908 to .912 , and the extracted average values of variance lay between .663 and .674 . This evidence supports the convergent validity of the measurement model, as shown in Tables 1.

Bagozzi and Phillips (1982) stated that metrics support discriminant validity if the upper and lower limits of the computed confidence interval did not include the number 1 . In the present research, a model was constructed for each of the 3-paired correlations of the latent variables. Then, the correlation was set between the two constructs to 1 , and a 95 percent confidence interval was applied in order to apply a bootstrap. As the results, all values of paired correlations of the latent variables were from .522 to .880 , the number 1 is not included with the upper and lower limits of the confidence interval, which indicates discriminant validity among the theoretical constructs.

Table 1: Standardized parameter estimates, composite reliability and average variance extracted values for the structural model

\begin{tabular}{lllll}
\hline Construct & Indicator & Standardized Parameter Estimates & CR & AVE \\
\hline & A1 & .76 & & \\
Corporate & A2 & .78 & .908 & .664 \\
brand image & A3 & .83 & & \\
& A4 & .87 & & \\
& A5 & .83 & & \\
& B1 & .82 & .912 & .674 \\
Customer & B2 & .90 & & \\
satisfaction & B3 & .80 & & \\
& B4 & .79 & & \\
& B5 & .79 & .908 & \\
Customer & C1 & .78 & & \\
loyalty & C3 & 82 & .663 \\
& C4 & .81 & & \\
\hline
\end{tabular}


The results of the SEM model shown in Figure 2 were obtained using AMOS 18.0, and the model fits are reported in Table 2. The overall model fit $\chi^{2}$ was 208.639 with 87 degrees of freedom. The p-value associated with this result was .000. The $p$-value was significant using a type I error rate of .05; thus, the $\chi$ 2 goodness-of-fit statistic does not indicate that the observed covariance matrix matches the estimated covariance matrix within the sampling variance. According to previous research, a number of indices are available to evaluate model fits (Bentler, 1992; Fornell and Larcker, 1981; Jöreskog and Sörbom, 1992), but no single index or standard is generally agreed; hence, multiple criteria should be used to evaluate the overall fit of the theoretical model (Hair et al., 2010; Bagozzi and Yi, 1988). The value of RMSEA, an absolute fit index, was .084. This value is smaller than the guideline value of .10 for a model with 15 measured variables and a sample size of 199. Therefore, RMSEA supports the model fit. The value of GFI (.862) was higher than the guideline value. RMR had a value .024, and SRMR (.047) was smaller than .05. The normed $\chi^{2}$ was 2.398. This measure is the chi-square value divided by the number of degrees of freedom. A number smaller than 3.0 is considered to be very good. Thus, the normed $\chi^{2}$ suggests an acceptable fit for the structural model.

In the SEM model, the CFI had a value of .945, which exceeds the CFI guidelines for a model of this complexity and sample size. The other incremental fit indices (NFI $=.11$ ) also exceeded the suggested cutoff values. All the incremental fit indices presented an acceptable fit. The parsimony index of AGFI had a value of .809 and the PNFI was .755. Both indices were considered to represent a good model fit, given the acceptable critical value. The overall structural fit results of these analyses showed that the model provides a reasonable fit.

Table 2: Comparisons of goodness-of-fit indices of SEM models

\begin{tabular}{lll}
\hline GOT Indices & Criterion Guidelines & SEM Results \\
\hline Chi-square $\left(\chi^{2}\right)$ & & 208.639 \\
Chi-square & & 87 \\
Degree of freedom & $>.05$ (Jöreskog \& Sörbom, 1992) & .000 \\
Probability & $>.80$ (MacCallum \& Hong, 1997) & .862 \\
Absolute fit measures & $<.10$ (Steiger, 1990) & .084 \\
GFI & $<.05$ (Wu, 2009) & .024 \\
RMSEA & $<.05$ (Jöreskog \& Sörbom, 1992) & .047 \\
RMR & $<3$ (Hair et al., 2010) & 2.398 \\
SRMR & $>.90$ (Bentler, 1992) & .911 \\
Normed chi-square & $>.90$ (Gerbing \& Anderson, 1992) \\
Incremental fit measures & $>.80$ (MacCallum \& Hong, 1997) \\
NFI & $>.50$ (Wu, 2009) & .945 \\
CFI & & .809 \\
Parsimony fit measurement & & .755 \\
AGFI & &
\end{tabular}

For H1, The value of the standardized parameter estimates was .712. The standard error was .083, and the $t$-value was significant $\left(\mathrm{p}=8.597^{* * *}\right)$. For $\mathrm{H} 2$, The value of the standardized parameter estimates was .366. The standard error was .064, and the $t$-value was significant $\left(\mathrm{p}=.5 .737^{* * *}\right)$. For H3, The value of the standardized parameter estimates was .435. The standard error was .071, and the t-value was significant $\left(\mathrm{p}=6.129^{* * *}\right)$.

Table 3: Standardized parameter estimates for the structural model

\begin{tabular}{lllll}
\hline Hypotheses & Estimates & S. E. & t-value & P \\
\hline $\mathrm{H} 1$ & .712 & .083 & 8.597 & $* * *$ \\
$\mathrm{H} 2$ & .366 & .064 & 5.737 & $* * *$ \\
\hline
\end{tabular}




\begin{tabular}{lrrrr}
\hline $\mathrm{H} 3$ & .435 & .071 & 6.129 & ${ }^{* * *}$ \\
\hline${ }^{*} \mathrm{p}<.05 .^{* *} \mathrm{p}<.01 .^{* * *} \mathrm{p}<.001$. & & &
\end{tabular}

Figure 2: SEM Model

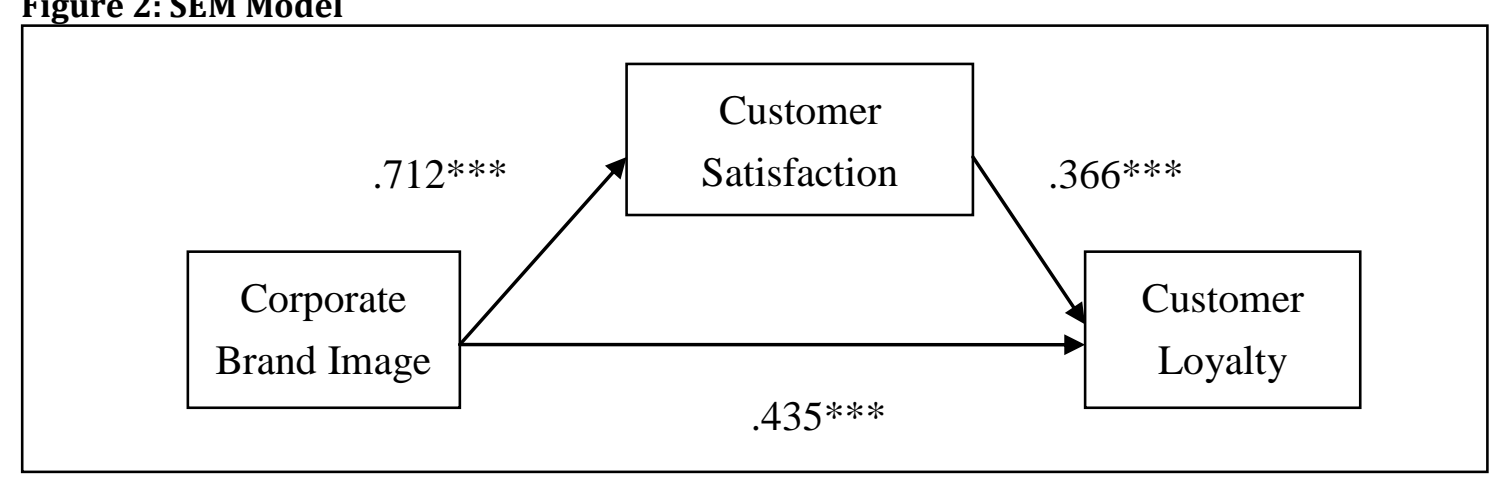

\section{Conclusion}

The results of this study show that the corporate brand image is a direct path and is a factor that significantly affects the customer satisfaction. The finding supports $\mathrm{H} 1$ and the result are consistent with the findings of Johnson, Andreessen, Lervik \& Cha, (2001); and Davies et al. (2003). For hypothesis 2, the results indicate that the customer satisfaction is a direct path and is a factor that significantly affects the customer loyalty. Therefore, this hypothesis is supported, and the result is consistent with the findings of Eakuru and Mat (2008). For hypothesis 3, the results indicate that the corporate brand image is a direct path and is a factor that significantly affects the customer loyalty. Therefore, this hypothesis is supported, and the result is consistent with the findings of Ogba \& Tan (2009), Johnson, Andreessen, Lervik, \& Cha (2001); Martineau (1958); and Selnes (1993).

Based on the research results, the corporate brand image significantly affects customer satisfaction and customer loyalty, and customer satisfaction has strong impact on customer loyalty for the sample. Therefore, firms have to specifically focus on these factors in order to build a long-term and mutually profitability relationship with a customer and create loyalty as competitive advantages in the market. From the respondents, Starbucks Coffee should also pay more attention to male, young customers who are under 35 years old, and consumers who have a high school diploma or equivalent and associate degree for increasing market share. The study focuses on coffee industry in Taipei area, and adopts only a quantitative research method. Although the SEM provides a good fit to the hypothesized model, future research could use a different design to examine the causal relationships posited by the theories, such as marketing mix (4Ps) and relationship quality, to explore other antecedents on loyalty, and should be conducted in other industries and other Asian countries or different global regions.

\section{References}

Aaker, J. L. (1997). Dimensions of brand personality. Journal of Marketing Research, 34(3), 347-357.

Bagozzi, R. \& Phillips, L. (1982). Representing and testing organizational theories: A holistic construal. Administrative Science Quarterly, 27, 459-489.

Bagozzi, R. P. \& Yi, Y. (1988). On the Evaluation of Structure Equations Models. Academic of Marketing Science, 16(1), 76-94.

Bennett, R. \& Rundle-Thiele, S. (2002). A comparison of attitudinal loyalty measurement approaches. Journal of Brand Management, 9(3), 193-207.

Bentler, P. M. (1992). On the Fit of Models to Covariance and Methodology to the Bulletin. Psychological Bulletin, 112, 400-404. 
Bloemer, J. M. M. \& Odekerken-Schroder, G. (2002). Store satisfaction and store loyalty explained by customer- and store-related factors. Journal of Consumer Satisfaction, Dissatisfaction and Complaining Behavior, 15, 68-79.

Bollen, K. A. (1989). Structural equations with latent variables. Newbury Park, CA: Sage.

Bowen, J. T. \& Shoemaker, S. (2003). Loyalty: A strategic commitment. Cornell Hotel \& Restaurant Administration Quarterly, 44(5/6), 31-46.

Caceres, R. C. \& Paparoidamis, N. G. (2007). Service quality, relationship satisfaction, trust, commitment and business-to-business loyalty. European Journal of Marketing, 41(7/8), 836-867.

Davies, G., Chun, R., Da-Silva, R. \& Roper, S. (2003). Corporate Reputation and Competitiveness. Routledge, UK: London.

Davies, G. \& Chun, R. (2002). Gaps between the internal and external perceptions of the corporate brand. Corporate Reputation Review, 5, 144-158.

De-Chernatony, L. (1999). Brand Management through narrowing the gap between brand identity and brand reputation. Journal of Marketing Management, 15, 39-56.

De-Chernatony, L. \& Harris, F. (2000). Developing corporate brands through considering internal and external stakeholders. Corporate Reputation Review, 3(3), 268-274.

Dick, A. S. \& Basu, K. (1994). Customer Loyalty: Toward an Integrated conceptual Framework. Journal of Academy of Marketing Science, 22(2), 99-113.

Dimitriades, Z. S. (2006). Customer satisfaction, loyalty and commitment in service organizations: Some evidence from Greece. Management Research News, 29(12), 787-799.

Eakuru, N. \& Mat, N. K. N. (2008). The application of structural equation modeling (SEM) in determing the antecedents of customer loyalty in banks in South Thailand. The Business Review, Cambridge, 10(2), 129-139.

Engel, J. F. \& Blackwell, R. D. (1982). Consumer Behavior. New York: Holt, Rinehart, and Winston.

Fornell, C. \& Larcker, D. F. (1981). Evaluating Structural Equation Models with Unobservable Variables and Measurement Error. Journal of Marketing Research, 18, 39-50.

Gerbing, D. W. \& Anderson, J. C. (1992). Monte Carlo evaluations of goodness of fit indices for structural equation models. Sociological Methods Research, 21, 132-160.

Grahn, G. L. (1969). NBD model of repeat-purchase loyalty: An empirical investigation. Journal of Marketing Research, 6(1), 72-78.

Hair, J. F., Black, W. C., Babin, B. J. \& Anderson, R. E. (2010). Multivariate data analysis. Pearson, NJ: Pearson Education Inc.

Hunt, K. H. (1977). Customers Satisfaction/Dissatisfaction--Overview and Future Directions, Conceptualization and Measurement of Customer. Marketing Science Institute, Cambridge, MA.

Ibrahim, H. \& Najjar, F. (2008). Relationship bonding tactics, personality traits, relationship quality and customer loyalty: Behavioral sequence in retail environment. The Icfai University Journal of Services Marketing, 6(4), 1-37.

Ind, N. (1997). The Corporate Brand. Macmillan Press Ltd, Great Britain.

Jacoby, J. (1971). A model of multi-brand loyalty. Journal of Advertising Research, 11(3), 25-31.

Jacoby, J. \& Chestnut, R. W. (1978). Brand Loyalty: Measurement and Management. New York: John Wiley.

Johnson, M. D., Andreessen, T. W., Lervik, L. \& Cha, J. (2001). The evolution and future of national customer satisfaction index models. Journal of Economic Psychology, 22, 217-245.

Johnson, M. D., Anderson, E. W. \& Fornell, C. (1995). Rational and adaptive performance expectations in a customer satisfaction framework. Journal of Consumer Research, 21, 695-707.

Jones, T. (1996). Why satisfied customer defect. Journal of Management in Engineering, 12(6).

Jöreskog, K. G. \& Sörbom, D. (1992). LISREL: A Guide to the Program and Applications. 3rd ed. Chicago: Scientific Software International, Inc.

Keller, K. L. (1993). Conceptualizing, Measuring, and Managing Customer-Based Brand Equity. Journal of Marketing, 57(1), 1-22.

Kline, R. B. (1998). Principles and Practice of Structural Equation Modeling. Guilford Press, New York.

Kotler, P. (2005). According to Kotler: The World's Foremost Authority on Marketing Answers the World's Foremost Authority on Marketing Answers Your Questions. New York: AMACOM.

Leech, N. L., Barrett, K. C. \& Morgan, G. A. (2005). SPSS for intermediate statistics use and interpretation. Mahwah. Lawrence Erlbaum, NJ.

MacCallum R. C. \& Hong, S. (1997). Power Analysis in Covariance Structure modeling using. Multivariate Behavioral Research, 32, 193-210. 
Martenson, R. (2007). Corporate brand image, satisfaction and store loyalty. International Journal of Retail \& Distribution Management, 35(7), 544-555.

Martineau, P. (1958). The personality of retail store. Harvard Business Review, 36(1), 47-55.

Ogba, I. E. \& Tan, Z. (2009). Exploring the impact of brand image on customer loyalty and commitment in China. Journal of Technology Management in China, 4(2), 132-144.

Oliver, R. L. (1997). Satisfaction: A Behavioral Perspective on the Consumer. New York: McGraw Hill.

Olsen, L. L. \& Johnson, M. D. (2003). Service equity, satisfaction, and loyalty: From transaction-specific to cumulative evaluations. Journal of Service Research, 5(3), 184-195.

Porter, S. S. \& Claycomb, C. (1997). The influence of brand recognition on retail store image. The Journal of Product and Brand Management, 6, 373-384.

Reichheld, F. F. \& Detrick, C. (2003). Loyalty: A prescription for cutting costs. Marketing Management, 12(5), 24-25.

Reichheld, F. F. \& Teal, T. (1996). The Loyalty Effect: The Hidden Force Behind Growth, Profits, and Lasting Value. Boston, Mass: Harvard Business School Press.

Reichheld, F. F. \& Sasser, W. E. J. (1990). Zero defections Quality comes to services. Harvard Business Review, 68(5), 105-111.

Roig, J. G. F., Garcia, J. S., Tena, M. A. M. \& Monzonis, J. L. (2006). Customer perceived value in banking services. International Journal of Bank Marketing, 24(5), 266-283.

Selnes, F. (1993). An examination of the effect of product performance on brand reputation, satisfaction and loyalty. European Journal of Marketing, 27(9), 19-35.

Steenkamp J. B. E. M., Van-Trijp H. C. M. (1991). The use of LISREL in validating marketing constructs. International Journal of Research in Marketing 8, 283-299.

Steiger, J. H. (1990). Structural model evaluation and modification: An interval estimation approach. Multivariate Behavioral Resaerch, 25, 173-180.

Wills, B. (2009). The business case for environmental sustainability (Green): Achieving rapid returns from the practical integration of lean \& green. Business Case for Environmental Sustainability. Retrieved June, 2010, from http://www.leanandgreensummit.com/LGBC.pdf

Woodruff, R. B. (1997). Customer value: The next source for competitive advantage. Academy of Marketing Science, 25(2), 139-153.

$\mathrm{Wu}$, C. C. (2011). The impact of hospital brand image on service quality, patient satisfaction and loyalty. African Journal of Business Management, 5(12), 4873-4882.

Wu, M. L. (2009). Structural equation modeling: Amos operation and application. Wu-Nan Book Inc, Taipei, Taiwan. 